\title{
Etnomatematika pada bangunan Umbul Binangun dalam aktivitas pembelajaran matematika
}

\author{
Ryopanintama Yuniar Putra, Davet Nur Alviyan, Tri Astuti Arigiyati, Krida Singgih \\ Kuncoro* \\ Fakultas Keguruan dan Ilmu Pendidikan, Universitas Sarjanawiyata Tamansiswa. \\ * Corresponding Author. E-mail: krida.kuncoro@ustjogja.ac.id
}

Submitted: 26 November 2020 | Revised: 30 Maret 2021 | Accepted: 30 Maret 2021 | Available Online: 12 April 2021

\begin{abstract}
Abstrak
Penelitian ini dilakukan untuk menemukan unsur-unsur matematika (etnomatematika) pada bangunan Umbul Binangun yang berada di Yogyakarta, Indonesia. Penelitian ini menggunakan metode kualitatif dengan pendekatan etnografi. Data-data yang dipakai adalah data yang didapat dari studi literatur, observasi, dokumentasi, dan wawancara. Observasi dan dokumentasi digunakan untuk mengidentifikasi etnomatematika pada bangunan Umbul Binangun. Sedangkan literatur dan wawancara digunakan untuk mengetahui lebih dalam nilai-nilai budaya yang ada pada bangunan Umbul Binangun. Hasil dari penelitian ini adalah terdapat unsur-unsur matematika (etnomatematika) pada bangunan Umbul Binangun, yaitu konsep persegi panjang, lingkaran, belah ketupat, dan garis sejajar. Melalui kegiatan mengamati bangunan Umbul Binangun dalam pembelajaran matematika dengan pendekatan etnomatematika menjelaskan bahwa unsur budaya dapat digunakan dalam pembelajaran matematika.
\end{abstract}

Kata Kunci: aktivitas matematika, etnomatematika, geometri, Umbul Binangun

\section{Ethnomathematics at Umbul Binangun Building for geometry learning}

\begin{abstract}
This research was conducted to study mathematical elements (ethnomathematics) in the Umbul Binangun building that is located in Yogyakarta, Indonesia. The research used a qualitative method with an ethnographic approach. The data were obtained from literature studies, observation, documentation, and interviews. Observation and documentation were used to identify ethnomathematics in the Umbul Binangun building. Meanwhile, literature and interviews were used to investigate more deeply about the cultural values that exist in the Umbul Binangun building. The results show elements of mathematics (ethnomathematics) in the Umbul Binangun building contain geometry aspects, namely the concept of rectangles, circles, rhombuses, and parallel lines. Observing the Umbul Binangun building in mathematics learning with ethnomathematics explains that cultural elements can be used in learning mathematics.
\end{abstract}

Keywords: ethnomatematics, geometry, mathematical activities, Umbul Binangun

How to cite:

Putra, R. Y., Alviyan, D. N., Arigiyati, T. A., \& Kuncoro K. S. (2021). Etnomatematika pada bangunan Umbul Binangun Taman Sari dalam pembelajaran matematika materi geometri bidang datar. Ethnomathematics Journal, 2(1), 21-30. https://doi.org/10.21831/ej.v2i1.36081 


\section{PENDAHULUAN}

Bangsa Indonesia merupakan bangsa yang terkenal akan tradisi dan budaya yang beragam. Keanekaragaman budaya merupakan warisan dari nenek moyang (Prayitno, 2019). Menurut Ardiwidjaja (2018) warisan budaya adalah hasil budaya fisik dari tradisi-tradisi yang berbeda dan menjelaskan jati diri dari setiap daerah. Warisan budaya fisik banyak diartikan sebagai warisan budaya tidak bergerak dan warisan budaya bergerak. Warisan budaya tidak bergerak yaitu tempattempat yang memiliki sejarah seperti halnya bangunan kuno dan patung-patung pahlawan (Mardika, 2019). Warisan budaya yaitu sesuatu benda, adat istiadat atau pola perilaku yang harus dijaga dan dilestarikan, hal ini searah dengan pernyataan Nocca (2017) yang menyatakan bahwa warisan budaya (cultural heritage) yaitu perangkat-perangkat simbol kolektif yang sudah diturunkan secara turuntemurun dari generasi sebelumnya yang dapat berupa fisik, pola perilaku dan pandangan hidup. Warisan budaya yang memiliki nilai penting, salah satunya adalah pada kawasan Tamansari Umbul Binangun yang merupakan bangunan bekas istana air dan menjadi bagian dari Jeron Beteng Kraton Yogyakarta (Arvisista \& Dwisusanto, 2020).

Taman Sari juga dikenal sebagai Istana Air. Taman Sari adalah sebuah taman bekas kerajaan Kesultanan Yogyakarta (Noviandri \& Sabono, 2018). Dibangun pada pertengahan abad ke-18 dan masing-masing bangunan mempunyai fungsi tersendiri, seperti area istirahat, bengkel, area meditasi, daerah pertahanan, dan tempat persembunyian. Taman Sari memiliki empat bidang yang berbeda, yaitu sebuah danau buatan dengan pulau dan paviliun yang terletak di sebelah barat, sebuah kompleks mandi di tengah, kompleks paviliun dan kolam di sebelah selatan, dan sebuah danau kecil di sebelah timur.

Umbul Binangun adalah bangunan pasiraman yang mempunyai fungsi untuk tempat pemandian bagi sultan, para istri, serta para putri keraton. Umbul Binangun berada di antara Gapura Agung dengan halaman Gedong Sekawan dan Gapura Panggung. Untuk memasuki area Umbul Binangun dapat dilalui dengan melewati dua buah pintu gapura yang terdapat di sisi barat atau timur Taman Sari. Umbul Binangun dikelilingi oleh tembok dengan tinggi 5,5 $\mathrm{m}$ setebal tebal 1,7 m, dan berukuran 20 x 65 m (Andini \& Rosandini, 2017). Umbul Binangun dihiasi dengan relief ukiran sengkalan memet yang menunjukkan tahun selesainya pembangunan Taman Sari (Andini \& Rosandini, 2017; Rista, Sinangjoyo, \& Damasdino, 2019). Pada Umbul Binangun terdapat tiga buah kolam atau pasiraman. Pada setiap pasiraman memiliki hiasan yaitu umbul yang berbentuk mirip dengan jamur dan pada tengahnya digunakan untuk mengeluarkan air mancur ke atas. Semua kolam membujur dari utara ke selatan. Setiap umbul tersebut memiliki masing-masing nama, yaitu: Umbul Kawitan yang memiliki fungsi sebagai tempat pemandian para putri raja, Umbul Pamuncar sebagai pemandian yang digunakan untuk istri dan selir raja, dan Umbul Panguras yang dipergunakan untuk kolam khusus untuk sang raja. Bentuk area Umbul Binangun dapat dilihat pada Gambar 1.

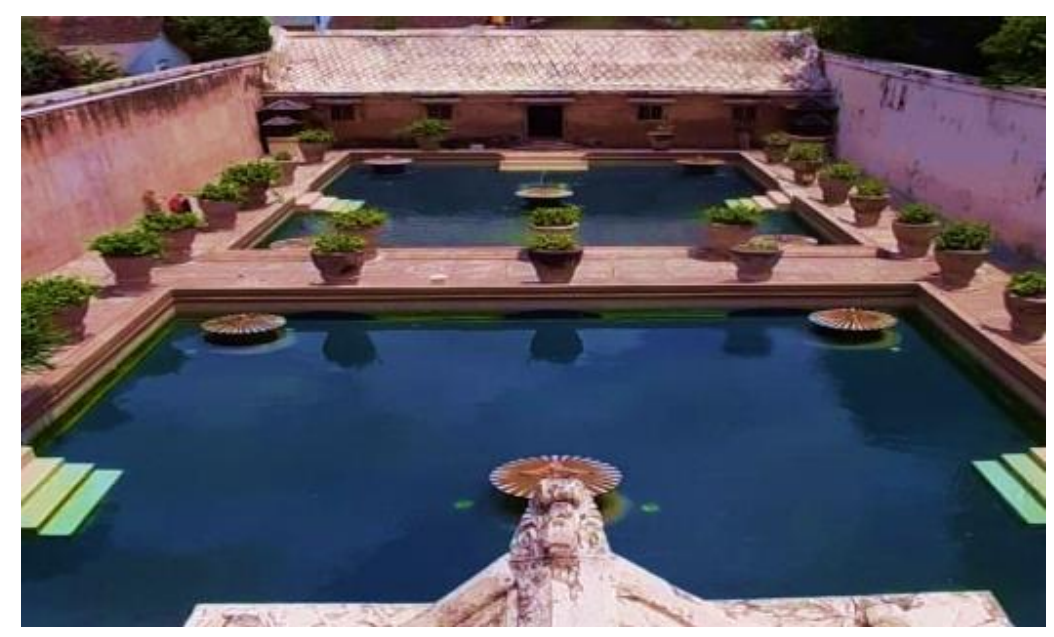

Gambar 1. Umbul Binangun Kraton Yogyakarta 
Bangunan-bangunan dan arsitektur pada Umbul Binangun apabila dilihat secara kasat mata menunjukkan berbagai perpaduan objek-objek matematika. Menurut Bishop (1991) matematika pada hakikatnya lahir dari aktivitas lingkungan budaya. Oleh karena itu, salah satu alternatif yang dapat digunakan untuk mempelajari matematika adalah melalui budaya, dalam matematika dikenal dengan istilah etnomatematika. Memanfaatkan budaya dalam mempelajari matematika merupakan hal yang sangat mungkin, karena Indonesia kaya akan khazanah budaya, mulai dari aktivitas, bangunan, bahkan peralatan sehari-sehari. Sependapat dengan Boaler (2015) yang menyatakan bahwa ide tentang budaya harus diintegrasikan ke dalam pembelajaran matematika untuk membantu peserta didik melihat kreativitas dan keindahan dalam mata pelajaran matematika.

Kendati demikian, anggapan matematika merupakan mata pelajaran yang sulit masih ada dalam benak peserta didik. Selain itu matematika juga masih dianggap terlalu teoritis (Saputra, 2019). Hal ini yang mendorong para guru untuk terus meningkatkan kemampuan dalam mengelola pembelajaran di kelas yaitu dengan pendekatan budaya. Sebuah pendekatan yang dapat digunakan untuk menjembatani hubungan antara matematika dan budaya adalah etnomatematika (Abi, 2017). Pendekatan budaya untuk mengajarkan matematika, di mana peserta didik menggunakan latar belakang sosial budaya mereka untuk menyusun konsep matematika akan membantu peserta didik melihat penerapan matematika dalam situasi kehidupan sehari-hari, sehingga dapat mengekstraksi kreativitas peserta didik dan keterampilan berpikir kritis (D'Ambrosio \& Rosa, 2017; Naresh, 2015; Orey \& de Oliveira Cortes, 2020; Widodo, Pangesti, Istiqomah, Kuncoro, \& Arigiyati, 2020).

Media pembelajaran yang dekat dengan peserta didik diperlukan untuk mewujudkan pembelajaran matematika yang bermakna (Kuncoro, Suyitno, \& Sugiharti, 2014; Setiawan, Wahyu, \& Sunardi, 2018). Media pembelajaran yang dekat dengan peserta didik dan memiliki unsur matematika salah satunya adalah dengan menganalisis nilai-nilai matematika yang terkandung dalam Umbul Binangun. Bagian Umbul Binangun yang unik dan dapat dijadikan sebagai objek dalam pembelajaran matematika. Tujuan dari penelitian ini adalah untuk mengungkap aktivitas pembelajaran matematika yang terdapat pada bangunan Umbul Binangun.

\section{METODE}

Penelitian yang dilakukan ini merupakan jenis penelitian deskriptif kualitatif dengan pendekatan etnografi, deskriptif kualitatif yaitu penelitian tentang riset yang menghasilkan data deskriptif berupa kata-kata tertulis dari latar secara utuh atau holistik (Moleong, 2013). Moleong (2013) menjelaskan bahwa penelitian kualitatif prosedur penelitian yang nantinya akan menghasilkan data deskriptif berbentuk kata-kata. Dijelaskan lebih lanjut, pengumpulan data dapat dilaksanakan melalui wawancara, dokumentasi dan observasi secara detail yang dapat menghasilkan data deskriptif guna menjelaskan sebab dan proses terjadinya peristiwa yang dialami oleh subjek penelitian.

Metode etnografi adalah ilmu penulisan mengenai suku bangsa dengan penggunaan bahasa yang lebih kontemporer, etnografi dapat juga memiliki arti sebagai penulisan mengenai suatu kelompok budaya (Sugiarto, 2017). Metode etnografi digunakan untuk menjelaskan, menggambarkan, dan menganalisis unsur kebudayaan dalam suatu masyarakat atau suku bangsa (Spradley, 2007). Menurut Fitrah dan Luthfiyah (2018) etnografi yaitu pembelajaran mengenai perilaku alami suatu budaya atau seluruh kelompok sosial. Dapat disimpulkan bahwa penelitian etnografi adalah penelitian kualitatif yang meneliti suatu kelompok atau masyarakat secara ilmiah yang bertujuan untuk mempelajari, mendeskripsikan, menganalisis, dan menafsirkan budaya pada suatu kelompok, baik pada hal perilaku, kepercayaan, bahasa, maupun pandangan yang dianut bersama

Teknik pengumpulan data dengan metode yang tepat merupakan langkah yang paling penting dalam penelitian, karena tujuan dari penelitian adalah mendapatkan data yang valid (Sugiyono, 2016). Dari segi langkah, teknik pengumpulan data dalam penelitian ini dilakukan dengan cara observasi, wawancara dan dokumentasi. Sesuai dengan jenis penelitian ini yaitu penelitian kualitatif dengan pendekatan etnografi, instrumen penelitiannya yaitu peneliti itu sendiri (human instrument). (Rukajat, 2018), menjelaskan dalam penelitian kualitatif, instrumen utama 
pengumpulan data adalah manusia, yaitu peneliti itu sendiri, atau orang yang membantu dalam proses penelitian. Dalam penelitian penelitilah yang berperan sebagai pengumpul data dan tidak boleh digantikan perannya oleh orang lain, jadi peran peneliti sendiri sebagai instrumen utama. Namun, selain peneliti yang sebagai instrumen utama perlu juga didukung oleh instrumen yang lainnya seperti menggunakan alat bantu berupa daftar pertanyaan

Pengumpulan data digunakan untuk mendapatkan data yang akurat dan relevan. Dalam penelitian ini, peneliti menggunakan studi pustaka, observasi, wawancara dan dokumentasi yang terkait dengan bangunan Umbul Binangun. Penyajian data yaitu mengumpulkan informasi yang tersusun yang memungkinkan adanya penarikan kesimpulan dan tindakan. Dalam penelitian ini penyajian data dilakukan dalam bentuk gambar dan uraian. Uraian data gambar yang disajikan yaitu mengenai nilai-nilai etnomatematika yang terkandung pada bangunan Umbul Binangun.

Menarik kesimpulan atau verifikasi yaitu cara menarik kesimpulan dari data yang disaji, kemudian diverifikasi dengan cara meninjau kembali studi pustaka dan hasil wawancara serta dokumentasi, menempatkan salinan suatu temuan dalam data, dan menguji data dengan memanfaatkan teknik keabsahan yang digunakan. Kesimpulan dalam penelitian kualitatif yaitu sebuah temuan yang baru dan belum pernah ada sebelumnya. Temuan dapat berbentuk deskripsi atau gambaran sebuah objek yang dulunya masih samar-samar atau gelap, sehingga dilakukan penelitian agar menjadi jelas. Oleh karena belum ada penelitian dengan judul serupa, maka penarikan kesimpulan dalam penelitian ini yaitu teridentifikasinya etnomatematika pada bangunan Umbul Binangun Tamansari.

\section{HASIL DAN PEMBAHASAN}

Objek wisata Pasiraman Umbul Binangun yang berada di kawasan Taman Sari merupakan salah satu objek wisata dan bangunan bersejarah yang terdapat di kota Yogyakarta. Taman Sari biasa dikenal juga dengan Istana Air (water castle) (Irawati, Priyanto, \& Kristiutami, 2019; Pratama, 2019). Dahulu, Taman Sari merupakan taman kerajaan Kesultanan Yogyakarta (Abdullah \& Panghastuti, 2018; Rista et al., 2019). Taman Sari tersebut digunakan untuk tempat pemandian para sultan dan keluarganya. Beberapa lokasi di Taman Sari, Kraton Yogyakarta diberi atribut dengan nama pasiraman atau umbul. Pasiraman memiliki makna yaitu tempat yang digunakan untuk mandi, sedangkan umbul berarti mata air yang keluar atau menyumbul. Umbul merupakan penanda tempat yang digunakan bagi sultan, permaisuri, selir, dan anak-anak sultan untuk mandi. Pada bangunan pemandian Umbul Binangun terbagi menjadi tiga kolam, yaitu Umbul Muncar yang digunakan untuk para putra-putri sultan, Blumbang Kuras yang digunakan untuk selir-selir sultan, dan Umbul Binangun yang digunakan untuk sultan dan permaisuri. Denah Umbul Binangun dapat dilihat pada Gambar 2.

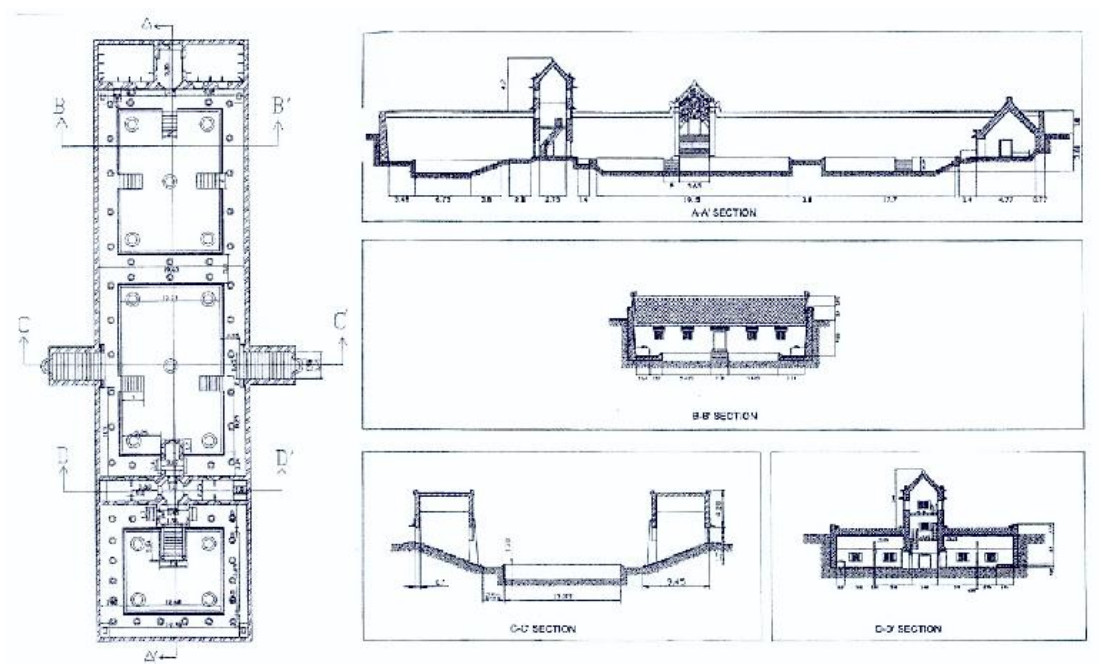

Gambar 2. Denah Umbul Binangun 
Sumber: (Gubernur Daerah Istimewa Yogyakarta, 2020)

Berdasarkan dari hasil eksplorasi, pemandian Umbul Binangun mempunyai objek-objek etnomatematika yang dapat digunakan dalam proses pembelajaran matematika. Umbul Binangun memiliki arsitektur berbentuk balok, jika Umbul Binangun dipandang dari atas dalam geometri bidang maka akan menjadi bentuk persegi panjang seperti yang dapat dilihat pada Gambar 3. Pada model bentuk geometri bidang Umbul Binangun jika mengaitkannya dalam matematika dapat menemukan sifat-sifat persegi panjang yaitu: 1.) Persegi panjang adalah segi empat yang keempat sudutnya siku-siku $\angle A=\angle B=\angle C=\angle D=90^{\circ} ;$ 2.) $\overline{A D} / / \overline{B C}$ dan $\overline{A B} / / \overline{D C} ;$ 3.) $\overline{A D}=$ $\overline{B C}$ dan $\overline{A B}=\overline{D C}$ dan $\overline{A C}=\overline{B D}$; dan 4.) $\overline{A O}=\overline{O C}$.

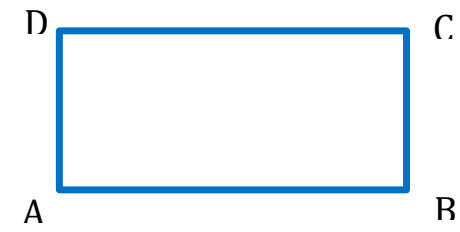

Gambar 3. Geometri Bidang pada Umbul Binangun

Selain konsep persegi panjang yang terdapat pada bentuk pemandian Umbul Binangun, tangga yang digunakan untuk memasuki pemandian juga memiliki konsep matematika berbentuk persegi panjang. Tangga pada pemandian Umbul Binangun dapat dilihat pada Gambar 4.
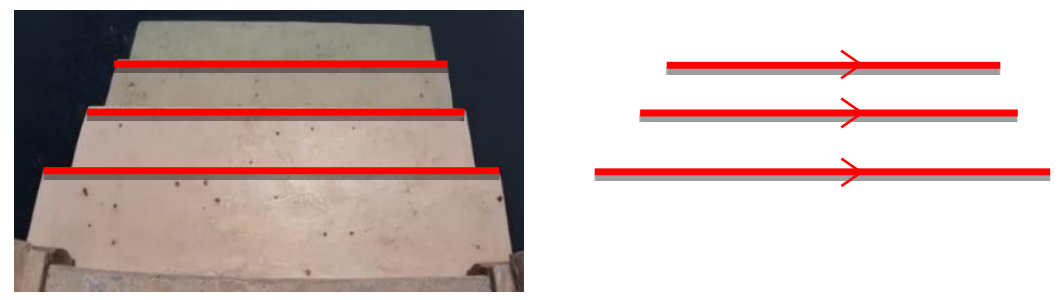

Gambar 4. Tangga Pemandian Umbul Binangun

Selain memiliki unsur geometri bidang berbentuk persegi panjang juga terdapat unsur matematika yang lain berupa garis lurus dan sejajar. Pada gapura bangunan pemandian Umbul Binangun memiliki bentuk bangun datar yang bermacam salah satunya pada Gapura Agung yang dapat dilihat pada Gambar 5. Pada Gapura Agung terdapat relief yang apabila dimodelkan dalam bidang geometri maka akan berbentuk geometri bidang sebuah lingkaran. Pada Gapura Agung jika terdapat sifat-sifat lingkaran dengan pemodelan relief gapura bangunan pemandian Umbul Binangun, yaitu: 1.) Garis yang menghubungkan sebuah sisi lingkaran dengan titik pusat dinamakan jari-jari $(r=$ radius). $\overline{O A}=\overline{O B}=\overline{O C}=r=$ jari - jari; 2 .) Garis yang menghubung dua buah titik pada suatu keliling lingkaran dinamakan tali busur. $\overline{A D}$ adalah suatu talibusur; dan 3.) Tali busur yang melalui titik pusat, namanya diameter. $\overline{A C}$ adalah garis tengah atau diameter.

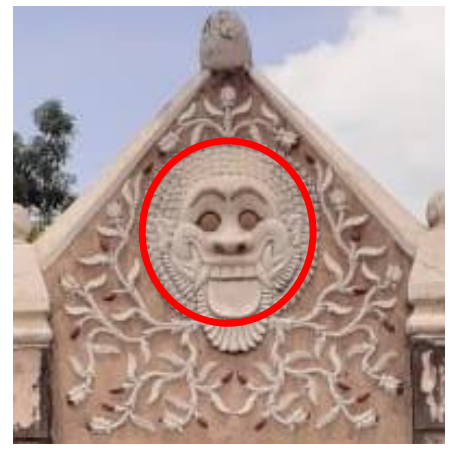

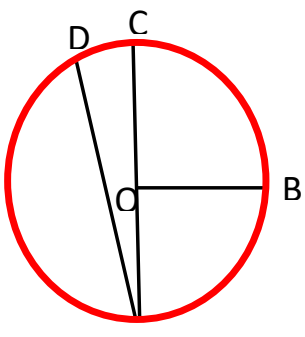

A 


\section{Gambar 5. Gapura Agung}

Selain itu, konsep lingkaran juga dapat ditemukan melalui sudut pandang dari atas bahwa umbul atau tempat air memancur dan pot-pot bunga yang terdapat pada pemandian Umbul Binangun. Umbul atau tempat air memancur dapat dilihat pada Gambar 6. Pada pemandian Umbul Binangun di sebelah utara dan selatan terdapat tempat untuk beristirahat dan pada bagian atapnya dapat menemukan model bidang datar geometri yang lain yaitu belah ketupat. Atap bangunan pada Umbul Binangun yang membentuk model bidang belah ketupat dapat dilihat pada Gambar 7.

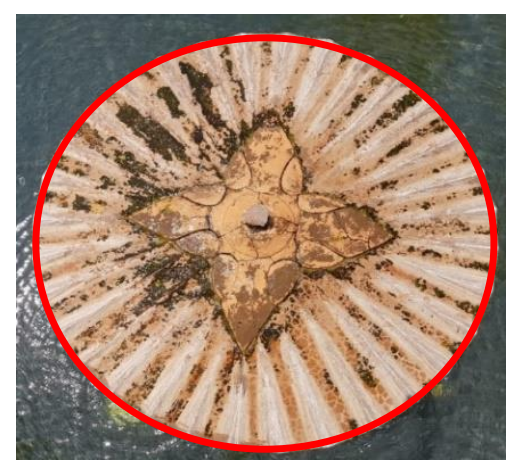

Gambar 6. Umbul atau Tempat Air Memancur
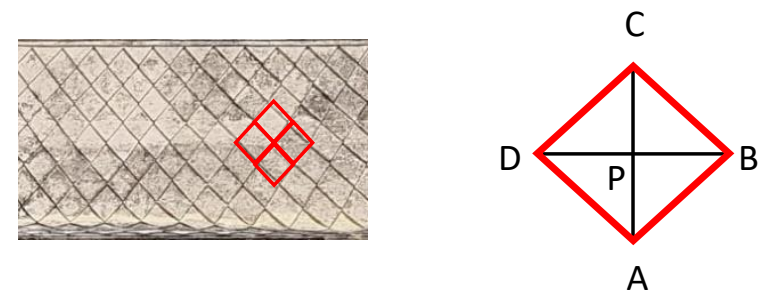

Gambar 7. Atap Bangunan Tempat Beristirahat

Atap bangunan pada Umbul Binangun jika dikaitkan ke dalam matematika memiliki model atau bentuk geometri bidang yaitu belah ketupat sebagaimana yang dapat dilihat pada Gambar 7 . Belah ketupat yaitu segi empat yang keempat sisinya sama panjang. Sifat-sifat belah ketupat ABCD antara lain: 1.) $\overline{A B}=\overline{B C}=\overline{C D}=\overline{D A}$ ukuran sisi-sisinya memiliki panjang sama; 2.) $\angle A B C=$ $\angle A D C$ dan $\angle B C D=\angle B A D$, sudut-sudut yang berhadapan sama besar serta dibagi dua oleh diagonalnya dengan sama besar; 3.) $\overline{A D} / / \overline{B C}$ dan $\overline{A B} / / \overline{D C}$; dan 4.) $\overline{A P}=\overline{C P}$ dan $\overline{B P}=\overline{B P}$.

Forbes (2018) menyatakan bahwa terdapat tiga aspek yang perlu diperhatikan apabila akan menerapkan etnomatematika dalam pembelajaran, yaitu: 1.) Membuat matematika menjadi bermakna; 2.) Memperbanyak kegiatan praktik matematika dalam kelas; dan 3.) Mendesain tugastugas matematik yang banyak berkaitan dengan budaya. Berdasarkan beberapa objek etnomatematika yang terdapat dalam bangunan Umbul Binangun, aktivitas dalam pembelajaran matematika yang dapat dilakukan antara lain: membelajarkan segitiga, kekongruenan garis dan sudut, kesejajaran garis, segitiga, segi empat, lingkaran, keliling, luas, pola bilangan. Materi garis dan sudut untuk memberikan aktivitas dalam mengukur besar sudut dapat dilihat pada Gambar 8 .

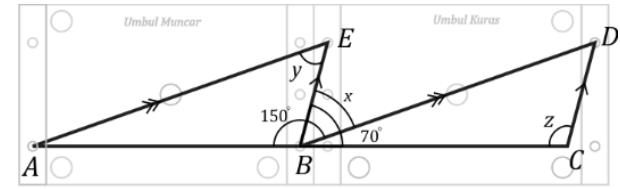

Perhatikan denah di atas. Hitunglah sudut $x, y, z$.

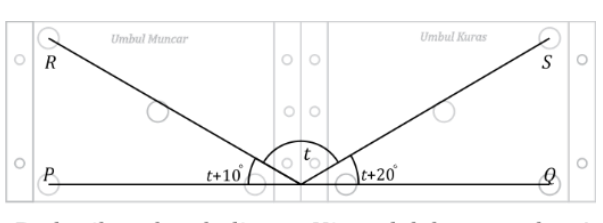

Perhatikan denah di atas. Hitunglah besar sudut $t$ !.

Gambar 8. Aktivitas Pembelajaran Matematika di Umbul Binangun pada Materi Garis dan Sudut 
Contoh aktivitas pembelajaran matematika pada Umbul Binangun yang berkaitan dengan kesejajaran garis dapat dilihat pada Gambar 9. Contoh aktivitas pembelajaran matematika pada materi kekongruenan segitiga dapat dilihat pada Gambar 10. Contoh aktivitas pembelajaran matematika yang berkaitan dengan konsep keliling dan luas segitiga dapat dilihat pada Gambar 11. Aktivitas pembelajaran matematika materi lingkaran dapat dilihat pada Gambar 12.

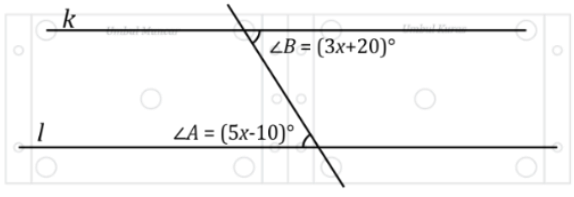

Garis $k$ sejajar garis $l$. Tentukan besar sudut $A$ dan sudut $B$ !

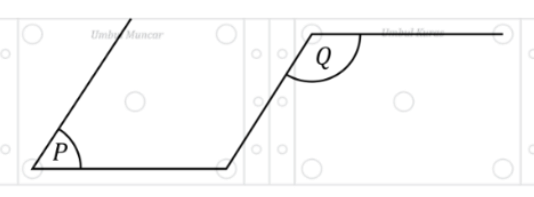

Dua pasang garis sejajar membentuk susunan seperti gambar di atas. Jika besar sudut $\mathrm{P}$ adalah $80^{\circ}$ tentukan besar sudut $\mathrm{Q}$ !

Gambar 9. Aktivitas Pembelajaran Matematika di Umbul Binangun pada Materi Kesejajaran Garis

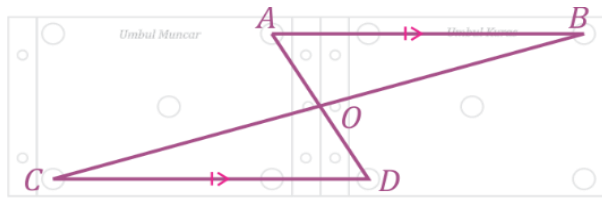

Diketahui $\mathrm{AB} \backslash \backslash \mathrm{CD}$ dan $\mathrm{AB}=\mathrm{CD}$, manakah pernyataan berikut yang benar?

(a) $\triangle \mathrm{AOB} \cong \mathrm{DOC}$

(b) $\triangle \mathrm{BOA} \cong \mathrm{DOC}$

(c) $\triangle \mathrm{AOB} \cong \mathrm{ODC}$

(d) $\triangle \mathrm{BAO} \cong \mathrm{COD}$

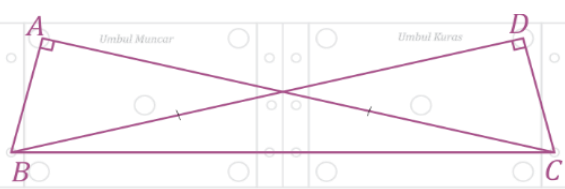

$\mathrm{AC}=\mathrm{BD}$ dan $\angle \mathrm{BAC}=\angle \mathrm{CDB}=90^{\circ}$. Jika $\triangle \mathrm{ABC} \cong \triangle \mathrm{DCB}$ menurut aksioma kekongruenan pada segitiga siku-siku Manakah di bawah ini yang dibutuhkan?

a) panjang $\mathrm{AB} \quad \mathrm{c}$ ) panjang $\mathrm{BC}$

b) panjang $C D$ d) $A C=B D$

Gambar 10. Aktivitas Pembelajaran Matematika di Umbul Binangun pada Materi Kekongruenan Segitiga

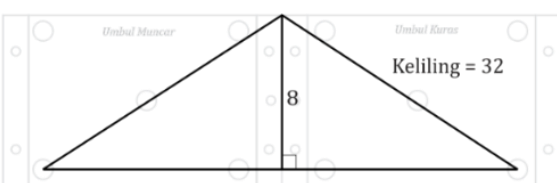

Tinggi sebuah segitiga sama kaki adalah 8 dan keliing segitiga tersebut 32 . Luas segitiga tersebut adalah? $\begin{array}{ll}\text { a. } 32 & \text { c. } 48\end{array}$

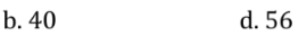

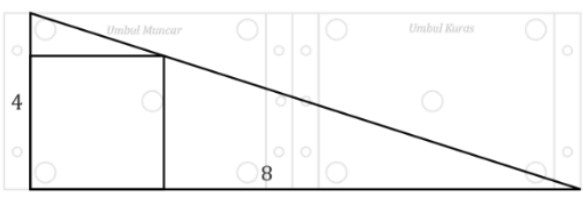

Pada segitiga siku-siku dengan sisi siku-siku 4 dan 8 , luas segi empat terbesar yang mungkin adalah?
a. $8 / 3$
c. $16 / 9$
b. $4 / 3$
d. $16 / 3$

Gambar 11. Aktivitas Pembelajaran Matematika di Umbul Binangun pada Materi Luas Segitiga
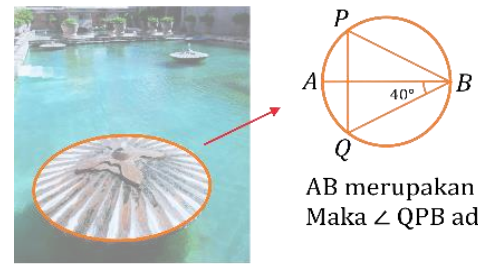

$\mathrm{AB}$ merupakan diameter lingkaran. Maka $\angle$ QPB adalah...

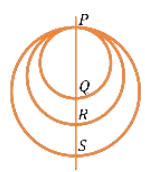

PQRS merupakan diameter dari tiga lingkaran. Luas lingkaran yang berada di tengah merupakan rata-rata dua lingkaran lainnya.

Jika $P Q=2, R S=1$ maka panjang $Q R$ adalah...

Gambar 12. Aktivitas Pembelajaran Matematika di Umbul Binangun pada Materi Lingkaran 
Aktivitas dalam pembelajaran matematika dengan menerapkan etnomatematika dapat lebih meningkatkan interaksi antara guru dengan peserta didik atau peserta didik dengan peserta didik lainnya (Febriani, Widada, \& Herawaty, 2019; Irawan \& Kencanawaty, 2017). Keterkaitan budaya dengan matematika berarti bahwa etnomatematika mampu memfasilitasi peserta didik, sehingga mampu mengkonstruksi pengetahuan dan konsep matematikanya itu sendiri (Suyitno, 2020). Menerapkan etnomatematika dalam pembelajaran matematika juga dapat menjadi salah satu sarana untuk memberi motivasi dan stimulasi kepada peserta didik untuk dapat mengatasi kejenuhan dan dapat memberikan nuansa baru kepada peserta didik dalam pembelajaran matematika (Forbes, 2018; Suyitno, 2020). Mengaitkan etnomatematika dengan praktik matematika yang dialami peserta didik membuat etnomatematika dekat dengan lingkungan sosial peserta didik, sehingga kegiatan belajar menjadi lebih menyenangkan (Mahendra, 2017; Maryati \& Pratiwi, 2019; Ulya \& Rahayu, 2017; Yohanes, Zaenuri, \& Budi, 2019).

\section{SIMPULAN}

Berdasarkan hasil dan pembahasan yang diperoleh dalam penelitian ini dapat disimpulkan bahwa pada Umbul Binangun yang terdapat dalam Taman Sari, Kraton Yogyakarta memiliki unsur matematika terutama pada geometri bidang datar. Unsur matematika tersebut bertujuan untuk menambah wawasan dalam mempelajari geometri melalui objek-objek geometri bidang datar yang terdapat dalam bangunan Umbul Binangun. Melalui aktivitas mengamati bangunan Umbul Binangun dalam pembelajaran matematika dengan pendekatan etnomatematika, menjelaskan bahwa unsur budaya dapat digunakan dalam pembelajaran matematika. Penelitian ini masih dalam batas eksplorasi, sehingga peneliti mengharapkan hasil penelitian ini dapat dikembangkan penelitian lebih lanjut. Oleh karenanya, Umbul Binangun yang memiliki unsur matematika terutama pada objekobjek geometri bidang datar dapat digunakan sebagai bahan ajar di sekolah sebagai alternatif selain buku paket yang sering digunakan sebagai pedoman pokok.

\section{DAFTAR PUSTAKA}

Abdullah, R., \& Panghastuti, T. (2018). Analisis hubungan antara bangunan bersejarah, mitos, budaya masyarakat lokal dengan motivasi wisatawan berkunjung di daya tarik wisata Tamansari Yogyakarta. Journal of Tourism and Economic, 1(1), 38-47. https://doi.org/10.36594/jtec.v1i1.20

Abi, A. M. (2017). Integrasi etnomatematika dalam kurikulum matematika sekolah. JPMI (Jurnal Pendidikan Matematika Indonesia), 1(1), 1-6. https://doi.org/10.26737/jpmi.v1i1.75

Andini, D. R., \& Rosandini, M. (2017). Pengolahan motif dari inspirasi ornamen Tamansari Keraton Yogyakarta. Atrat: Jurnal Seni Rupa, 5(3), 255-265. Retrieved from https://jurnal.isbi.ac.id/index.php/atrat/article/view/344

Ardiwidjaja, R. (2018). Arkeowisata: Mengembangkan daya tarik pelestarian warisan budaya (1st ed.). Yogyakarta: Deepublish.

Arvisista, A., \& Dwisusanto, Y. B. (2020). Transformation of Dalem Spatial Structure Around Jeron Beteng Area, Yogyakarta. Riset Arsitektur (RISA), 4(02), 138-154. https://doi.org/10.26593/risa.v4i02.3802.138-154

Bishop, A. J. (1991). Mathematical enculturation: A cultural perspective on mathematics education (Vol. 6). Dordrecht, The Netherlands: KluwerAcademic Publishers.

Boaler, J. (2016). Mathematical mindsets: Unleashing students' potential through creative math, inspiring messages and innovative teaching (1st ed.). San Fransisco: Jossey-Bass.

D'Ambrosio, U., \& Rosa, M. (2017). Ethnomathematics and its pedagogical action in mathematics education. In Ethnomathematics and its diverse approaches for mathematics education (pp. 285-305). https://doi.org/10.1007/978-3-319-59220-6_12 
Febriani, P., Widada, W., \& Herawaty, D. (2019). Pengaruh pembelajaran matematika realistik berbasis etnomatematika terhadap kemampuan pemahaman konsep matematika siswa SMA Kota Bengkulu. Jurnal Pendidikan Matematika Raflesia, 4(2), 120-135. https://doi.org/10.33449/jpmr.v4i2.9761

Fitrah, M., \& Luthfiyah, L. (2018). Metodologi penelitian: penelitian kualitatif, tindakan kelas \& studi kasus. Sukabumi: CV Jejak.

Forbes, W. A. (2018). Using ethnomathematics principles in the classroom: A handbook for mathematics educators (Faculty of Education, Brock University). Retrieved from https://dr.library.brocku.ca/handle/10464/13665

Gubernur Daerah Istimewa Yogyakarta. (2020). Keputusan Gubernur DIY Nomor 100 Tahun 2020 tentang Penetapan Kompleks Pasiraman Umbul Binangun Tamansari Kraton Yogyakarta sebagai Struktur Cagar Budaya Peringkat Provinsi. Daerah Istimewa Yogyakarta.

Irawan, A., \& Kencanawaty, G. (2017). Implementasi pembelajaran matematika realistik berbasis etnomatematika. Journal of Medives: Journal of Mathematics Education IKIP Veteran Semarang, 1(2), 74-81. Retrieved from http://ejournal.ivet.ac.id/index.php/matematika/article/view/483

Irawati, N., Priyanto, S. E., \& Kristiutami, Y. P. (2019). Analisis destination branding kawasan wisata Taman Sari melalui metode importance performance analysis. Media Wisata, 17(2), 2128. https://doi.org/10.36276/mws.v17i2.299

Kuncoro, K. S., Suyitno, A., \& Sugiharti, E. (2014). Keefektifan pembelajaran TPS berbantuan mouse mischief terhadap hasil belajar siswa. Kreano, Jurnal Matematika Kreatif-Inovatif (eJournal), 5(2), 205-211. https://doi.org/10.15294/kreano.v5i2.4551

Mahendra, I. W. E. (2017). Project based learning bermuatan etnomatematika dalam pembelajar matematika. Jurnal Pendidikan Indonesia, 6(1), 106-114. https://doi.org/10.23887/jpiundiksha.v6i1.9257

Mardika, I. M. (2019). Warisan budaya sebagai ikon pariwisata dalam rangka Kalimatan Timur menjadi Ibukota Negara. Ganaya: Jurnal Ilmu Sosial Dan Humaniora, 2(2-2), 57-62. Retrieved from https://jayapanguspress.penerbit.org/index.php/ganaya/article/view/372

Maryati, M., \& Pratiwi, W. (2019). Etnomatematika: Eksplorasi dalam tarian tradisional pada pembukaan asian games 2018. Fibonacci: Jurnal Pendidikan Matematika Dan Matematika, 5(1), 23-28. https://doi.org/10.24853/fbc.5.1.23-28

Moleong, L. J. (2013). Metodologi Penelitian Kualitatif; Cetakan ke 14. Bandung: PT. Remaja Rosdakarya.

Naresh, N. (2015). The role of a critical ethnomathematics curriculum in transforming and empowering learners. Revista Latinoamericana de Etnomatemática: Perspectivas Socioculturales de La Educación Matemática, 8(2), 450-471. Retrieved from https://www.revista.etnomatematica.org/index.php/RevLatEm/article/view/197

Nocca, F. (2017). The role of cultural heritage in sustainable development: Multidimensional indicators as decision-making tool. Sustainability, 9(10), 1882. https://doi.org/10.3390/su9101882

Noviandri, P. P., \& Sabono, F. (2018). Adaptasi bangunan cagar budaya Tamansari Yogyakarta terhadap perkembangan jaman melalui Soundscape. Seminar Ikatan Peneliti Lingkungan Binaan Indonesia (IPLBI) 3, 78-86. https://doi.org/10.32315/sem.3.a078

Orey, D. C., \& de Oliveira Cortes, D. P. (2020). Unity in differences: Reflections on the doing of ethnomodelling and dialogue through connecting ethnomathematics and modelling. In Ethnomathematics in Action (pp. 197-209). https://doi.org/10.1007/978-3-030-49172-7_11 
Pratama, R. N. Y. (2019). Visualisasi Sengkalan Memet Lajering Sekar Sinesep Peksi di Tamansari pada busana Cocktail (Institut Seni Indonesia Yogyakarta). Retrieved from http://digilib.isi.ac.id/id/eprint/6348

Prayitno, T. (2019). Mengenal produk nasional batik dan tenun (S. Susilo, Ed.). Semarang: ALPRIN.

Rista, R., Sinangjoyo, N. J., \& Damasdino, F. (2019). Membangun imajinasi wisatawan melalui pengalaman perjalanan di kawasan wisata warisan budaya. Media Wisata, 17(2), 103-119. https://doi.org/10.36276/mws.v17i2.312

Rukajat, A. (2018). Pendekatan penelitian kualitatif (qualitative research approach) (1st ed.). Yogyakarta: Deepublish.

Saputra, H. (2019). Pengaruh metode pembelajaran Think Pair Share (TPS) terhadap daya serap sswa pada mata pelajaran matematika pokok bahasan kubus dan balok di SMP Negeri 2 Sigli. Majalah Ilmiah Warta Dharmawangsa, 13(2). https://doi.org/10.46576/wdw.v0i60.415

Setiawan, T. B., Wahyu, S., \& Sunardi, S. (2018). Etnomatematika pada Pura Mandara Giri Semeru Agung sebagai bahan pembelajaran matematika. KADIKMA, 9(1), 156-164. https://doi.org/10.19184/kdma.v9i1.8441

Spradley, J. P. (2007). Metode Etnografi (Diindonesiakan oleh Misbah ZE). Yogyakarta: Tiara Wacana.

Sugiarto, E. (2017). Menyusun proposal penelitian kualitatif: Skripsi dan tesis. Yogyakarta: Suaka Media.

Sugiyono, S. (2016). Metode Penelitian Kuantitatif, Kualitatif, dan R\&D. Bandung: Alfabeta.

Suyitno, H. (2020). Ethnomatematika dalam pembelajaran matematika (sebuah kajian reflektif). Makalah dipresentasikan pada Seminar dan Konferensi Etnomatematika II.

Ulya, H., \& Rahayu, R. (2017). Pembelajaran etnomatematika untuk menurunkan kecemasan matematika. Jurnal Mercumatika : Jurnal Penelitian Matematika Dan Pendidikan Matematika, 2(1), 16-23. https://doi.org/10.26486/jm.v2i2.295

Widodo, S. A., Pangesti, A. D., Istiqomah, I., Kuncoro, K. S., \& Arigiyati, T. A. (2020). Thinking process of concrete student in solving two-dimensional problems. Jurnal Pendidikan Matematika, 14(2), 117-128. https://doi.org/10.22342/jpm.14.2.9460.117-128

Yohanes, K., Zaenuri, M., \& Budi, W. (2019). Kontribusi etnomatematika sebagai masalah kontekstual dalam mengembangkan literasi matematika. PRISMA: Prosiding Seminar Nasional Matematika, 2, 190-196. Retrieved from https://journal.unnes.ac.id/sju/index.php/prisma/article/view/28911 